\title{
Climate and the Rangelands of Canada ${ }^{1}$
}

\section{A. C. GARDER}

Agrometeorologist, Research Station, Beaverlodge, Alberta, Canada.

\section{Highlight}

Climate is only one of several forces that promote rangelands but it is often predominant. Climatic factors that favor the development of grass include the occurrence of extremes, recurring drought, prolonged periods of heat and cold, high winds, and perhumid conditions. Most of the grasslands of Canada fall within Köppen's climatic type "middle latitude dry" and summer drought plays a major role in their existence. There are other grasslands which evolve under quite different climatic regimes. These are much less extensive and with some climate is not the dominant cause. With one grassland form, however, climate does play a more direct role and the factors involved are almost the antithesis of those which have produced the vast rangelands of the semiarid Canadian west.

Climate is only one of a number of factors promoting natural grasslands, but it is the predominant one. Bioclimatologists have repeatedly pointed this out. Borchert (1950) in his excellent description of the climate of the North American grassland states "The vegetation gradients appear to coincide with the climatic gradients. If the pattern of climatic gradients changes, the vegetation pattern may be expected to tend to shift also, as it tended to do in [the drought

\footnotetext{
${ }^{1}$ Contribution No. NRG 69-7. Received August 23, 1969; accepted for publication December 1, 1969 .
} (1952) was convinced that there was a definite grassland climate and other investigators of climate-vegetation relationships are of the same opinion (Alderfer, 1959; Carpenter, 1940).

To point precisely to just what climatic factors promote and favor grassland ranges is difficult. The following appear to be important:

1. Continenlalily-Away from the moderating influence of the oceans, climates can assume extreme variability, especially in the higher latitudes where great changes in temperature as well years of] the 1930's." Thornthwaite as precipitation occur. Such climates are characterized by erratic precipitation amounts, both within the year and from year to year (Borchert, 1950). Temperature changes can be savage and unpredictable. As pointed out by Barnes (1959), grass can, on the whole, withstand these erratic extremes better than forest.

2. Drought-Recurrent drought favors the formation of coolseason grasses over trees. This fact is shown by Borchert (1950) in his treatise on the central North American plain. The moisture requirement of these grasses is only critical in spring and early summer. Late summer droughts in particular are easily withstood since grasses can aestivate during aridity and heat (Carpenter, 1940; Oosting, 1948).

3. Extended periods of coldAs manifested by the alpine meadow above the tree-line and the tundra north of the taiga, grasses are better able to survive long, intensely cold winters than trees (Barnes, 1959). Biel (1959) gives an interesting account of a limestone sinkhole, 450 feet deep, in the Austrian Alps. 
Temperatures $50 \mathrm{~F}$ lower at the bottom than at the rim have occurred. In the winter, temperatures of less than $-50 \mathrm{~F}$ (the lowest in central Europe) have been recorded and the frost-free season is exceptionally short. Only hardy grasses cover the bottom, but up the slope first stunted trees appear, then forest. This is a classical example of vertical plant stratification in reverse based on altitude because of a reversed temperature gradient.

4. Wind-Grasses are well adapted to withstand all manner of wind. Drying winds, both the cold of winter and the hot of summer, are less damaging to grasses than to trees (Klages, 1942). The same relationship prevails in those areas subject to the chinookthe warm wind of winter. Here trees can be winterkilled by desiccation when soil water is made unavailable to them by frost (Carder, 1961; Klages, 1942). Storm winds off the ocean also can be detrimental to trees. These winds can gain their effect by salt-spray (Tansley, 1949), but they can have an influence over sizeable areas quite distant from the sea as evinced by the grasslands of Kodiak Island off southwest Alaska and of certain parts of Newfoundland and England (Harvey and LegerGordon, 1953). With wind, grasses have a further advantage over trees for the tissues of grasses being near the ground escape some of the force of the wind, besides being more resilient (Biel, 1959).

5. Perhumid conditions-Grasses seem better able to stand wetter conditions than most trees as evidenced in marsh lands, swales, and coulecs (Barnes, 1959; Coupland, 1950). This relationship prevails under extreme oceanity, particularly if the perhumid conditions are associated with storm winds (Tansley, 1949).

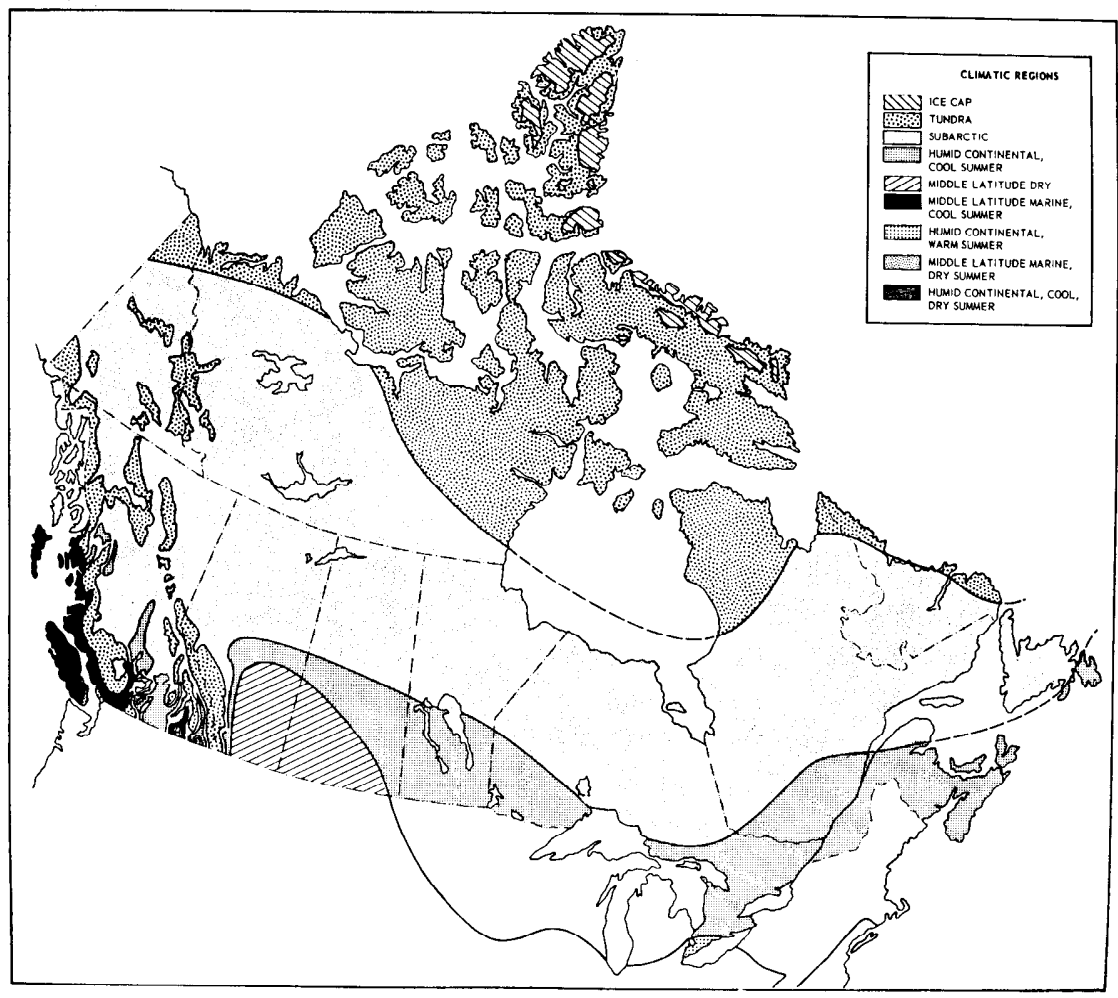

FIG. 1. Climatic Regions of Canada.

The importance of climate in its effect on vegetation can be seen by comparing maps depicting climate with those depicting types of vegetation. The close similarity between the climatic and vegetational boundaries is usually quite apparent (Harlan, 1959; Wilsie, 1962) (Figs. 1 and 2). This similarity remains even when the climatic map was developed without reference to vegetational zones as was done in the later Thornthwaite classifications of climate (Carter and Mather, 1966; Thornthwaite and Hare, 1955).

\section{Other Factors Promoting Grassland}

There are forces other than climate that determine the zonation of plants and these may assume on occasion a dominant role. To summarize:

1. Opportunity and competitionThese factors are so closely related that they can be knit as one. Whenever opportunity arises in the plant world there is compctition. The two factors relate to nature abhoring a vacuum and the ability of the plant species present to fill in after the forces creating the vacuum have dissipated.

2. Disturbance-This may be of short duration or continued almost indefinitely. Fire, whether natural or man-made, is a primary factor. Insects and disease predations and the influence of rodents and browsing animals can also bring about substantial degrees of disturbance.

3. Evolutionary flexibility-It is generally conceded that those species whose germ-plasm is responsive to change are better equipped to survive and multiply than plants less genetically adaptable (Rowe, 1965; Wilsie, 1962).

4. Geology-This has historical overtones and its influence is exerted through soil parent materials as well as physiography. The term "geology" includes besides the earth's composition and structure, the form of its 




Fig. 2. Vegetational Regions of Canada.

surface layer or landscape. From the plant aspect, therefore, geology determines such important features as drainage, elevation, and exposure of location.

5. Edaphic factors-The chemical composition, physical characteristics, and biotic properties of the soil frequently have a dominant influence on plant cover.

6. Geography and history-Geography determines place in space; history place in time. Geography is location: latitude, longitude, and distance and direction from the oceans. History is the past influencing the present. Prior climates, events and conditions can have lasting effects (Frenzel, 1968; Ritchie, 1965).

Interesting references have been made to the factors listed above. One pertaining to "opportunity" is given by Moore (1964) who points out the importance of the species available for colonization. He relates that in Australia there are woodlands whereas the same environment in North America is occupied by grass. This is because on the northern continent there are no woody species such as the eucalypts available that are adaptable to the "grassland climates" there. Mosquin (1965) questions the advantage under all environments of a plant having "evolutionary flexibility." IIe points to many sound reasons for believing that those plants best adaptive to the special environments of the boreal and tundra regions of Canada have reproductive specializations that promote genetic uniformity.

Climate and all the above factors may operate together, but usually only one or two become dominant. The influcnce of climatc may well be overridden. This is particularly true along climatic boundaries where often exist zones of biotic tension. Here, disturbance can become dominant in determining the typc of flora present. For instancc, Rowe (1965) relates that in west central Canada the position of the southern tree line of the boreal forest has been largely determined by fire, and Bird (1961) describes a southward shift of this forest-prairie boundary since the beginning of the century when agricultural development reduced the incidence of fires. Tansley (1949) strikingly describes how the activities of man, his sheep and, later, rabbits have maintained grasslands on the south down of England for thousands of years where the climate has for this full period favored the formation of forests.

\section{Climatic Classification and Vegetational Zones}

The ideal climatic classification for Canada has not been devised. The difficulty of constructing such a system is increased by the fact that the area contains very steep gradients in the moisture scale, east to west, and in the temperature scale, north to south. Sophisticated and declared rational systems such as those advanced by Thornthwaite in 1948 and 1955 fail to give proper emphasis to the drastic temperature gradient, at least when only the primary or so-called moisture index of these classifications is used (Carter and Mather, 1966; Sanderson, 1948). Moreover, the boundaries of such classifications are hard to comprehend for they do not employ straightforward, easily understandable climatic terms. On the other hand, Köppen's classification, despite limitations, does use simple temperature and precipitation values (Trewartha, 1954). Borchert (1950) in his thorough investigation of the climate of the central North American grasslands attempted to position this particular climate into the climatic regions of eastern America and found that his zones agreed very closely with those of Köppen. This prompted him to observe that "this coincidence appears to support the idea that, in general, the Köppen categories of climate are founded upon climatic regions which have a genetic basis and which have internal similarity in terms of their precipitation and related elements." There are according to the Köppen system, as modified slightly by Trewartha in 1954, nine climatic types in Canada 
Table 1. Climatic types in Canada according to the Köppen-Trewartha classification.

\begin{tabular}{cl}
\hline \hline Symbol & \multicolumn{1}{c}{ Climatic description } \\
\hline EF & $\begin{array}{l}\text { Ice cap. Polar winds summer and winter. } \\
\text { Meager precipitation throughout year. }\end{array}$ \\
ET $\quad \begin{array}{l}\text { Tundra. Polar winds summer and winter. } \\
\text { Meager precipitation throughout year. }\end{array}$ \\
Dcf $\quad \begin{array}{l}\text { Subarctic, humid microthermal. Westerlies } \\
\text { in summer, anticyclone and polar winds in } \\
\text { winter. Rain-snow climate with cold winters, } \\
\text { meager precipitation throughout year. }\end{array}$
\end{tabular}

Dbf Humid continental-cool summer. (Microthermal) Westerlies in summer, winter anticyclone. Rain in all seasons, accent on summer; long winter snow cover.

Dbs Humid continental-cool, dry summer. (Humid microthermal) Westerlies in summer, westerlies and winter anticyclone in winter.

Daf Humid continental-warm summer. (Humid microthermal) Westerlies in summer, westerlies and winter anticyclone in winter. Rain in all seasons, accent on summer; winter snow cover.

BSk Middle latitude dry. Continental winter anticyclone. Meager precipitation, most in summer.

Cbf Middle latitude marine-cool summer. (Humid mesothermal) Westcrlies summer and winter. Rain in all seasons, accent on winter.

Cbs

Middle latitude marine-dry summer. (Humid mesothermal) Westerlies summer and winter. Mediterranean-type climate.

Symbology

$\mathrm{EF}=$ all months below $32 \mathrm{~F}$

$\mathrm{ET}=$ temperature of warmest month below $50 \mathrm{~F}$, but above $32 \mathrm{~F}$

$\mathrm{D}$ = temperature of coldest month below $32 \mathrm{~F}$; warmest month over $50 \mathrm{~F}$

c = warmest month below $72 \mathrm{~F}$; less than four months above $50 \mathrm{~F}$

$\mathrm{f}=$ no dry season; driest month of summer over 1.2 inches
$\mathrm{b}$ = warmest month below $72 \mathrm{~F}$
$\mathrm{f}=$ no dry season; driest month of summer over 1.2 inches

$\mathrm{b}$ = warmest month below $72 \mathrm{~F}$

$\mathrm{s} \quad=$ summer dry; driest month less than 1.2 inches
$\mathrm{a}=$ warmest month above $72 \mathrm{~F}$
$\mathrm{f}=$ no dry season; driest month of summer over 1.2 inches
$\mathrm{B}=$ evaporation exceeds pre- cipitation
$\mathrm{S}=$ steppe type climate
$\mathrm{k}=$ coldest month $32 \mathrm{~F}$ or lower

$\mathrm{C}=$ coldest month between $61 \mathrm{~F}$ and $32 \mathrm{~F}$

$\mathrm{b}=$ warmest month below $72 \mathrm{~F}$

$\mathrm{f}=$ no dry season; driest month of summer over 1.2 inches

$\mathrm{b}=$ warmest month below $72 \mathrm{~F}$

$\mathrm{s} \quad=$ summer dry; driest month month less than 1.2 inches

Percent

of Canada

Location

3

Canada wide

18

East to mid-west and central interior of British Columbia

$<1$

Certain intermountain valleys in southern British Columbia

$<1 \quad$ Southern Ontario

Most in southeast Alberta and southwest Saskatchewan, some in southern British Columbia

1 Littoral of British Columbia

Southeast section of Vancouver Island of which only five prevail over any substantial amount of territory (Table 1 and Fig. 1).

\section{Climate and the Canadian Grasslands}

Where do the rangelands fit into this climatic classification? First there are the short-grass, mixedgrass, and tall-grass prairies. These make up the vast majority of the ranges of Canada and fall almost entirely into Köppen's "middle latitude dry" climatic type (Figs. 1 and 2). These grasslands arc a rcsponse to summer drought. Bor- dering them to the northeast, north, and northwest and far out from them in this last direction are the aspen parkland grasslands. These exist in a prairie-forest ecotone and, therefore, it is not surprising to find that they spread over into three climatic regions, the middle 
latitude dry type already mentioned, and the "humid continentalcool summer" and the "subarctic, humid microthermal” zones. These grasslands are a response in part to summer drought, but disturbance by fire and browsing over many hundreds of years is probably a more important cause for their presence (Rowe, 1965).

West of the Rocky Mountains are the intermountain grasslands of south and central British Columbia. The northern portion of these falls into Köppen's humid continentalcool summer climatic type, but the southern section comes under a somewhat different regime, a climate having very dry summers, termed in the Köppen scheme as "humid continental-cool dry summer." These southern grasslands are largely a response to winter moisture combined with summer drought (Woolfolk et al., 1948).

There remain three further rangeland types none of which is extensive. The first, boreal forest grasslands, which fall into the subarctic, humid microthermal climatic type are a result of either disturbance (Moss, 1952); history, i.e., a relic of a former climatic regime (Webb et al., 1967); geological, such as poor drainage; or an edaphic cause (Moss, 1952). The tundra ranges which are found in the northern portion of the subarctic, humid microthermal and "tundra" climates are extensive but at present little used commercially. These mixed grass-sedge-forb-lichen ranges are largely a response to cold. The presence of the maritime or seaboard ranges is more difficult to explain. Here, the part played by climate is mostly indirect. Such ranges are largely a response to edaphic factors, with disturbance and geology also playing important roles. Climate is probably directly involved in providing perhumid conditions and in certain instances a high degree of oceanity including storm winds. Such ranges fall within Köppen's subarctic and humid continental-cool summer types.

\section{Literature Cited}

Alderfer, R. B. 1959. Interrelations of physiology, ecology, and soil science: 27-37. In Grasslands. Pub. 53. Amer. Ass. Advancement Sci. Washington, D.C.

Barnes, C. P. 1959. The climatic environment of grassland: 243-249. In Grasslands. Pub. 53. Amer. Ass. Advancement Sci. Washington, D.C.

BIEL, E. R. 1959. Microclimate and grassland: 263-274. In Grasslands. Pub. 53. Amer. Ass. Advancement Sci. Washington, D.C.

BIRD, R. D. 1961. Ecology of the aspen parkland. Can. Dep. Agr. Res. Br. Pub. 1066. 155 p.

BorcherT, J. R. 1950. The climate of the central North $\Lambda$ merican grassland. Ann. Ass. Amer. Geogr. 60: 1-39.

Carder, A. C. 1961. Climate of the Beaverlodge area: 104-109. In Soil survey of the Beaverlodge and Blueberry Mountain sheets. Alberta Soil Survey Rep. 20.

Carpenter, J. R. 1940. The grassland biome. Ecol. Monogr. 10:618684.

Carter, D. B., and J. R. Mather. 1966. Climatic classification for environmental biology: 305-395. In Pub. in climatol. 19.

Coupland, R. T. 1950. Ecology of mixed prairie in Canada. Ecol. Monogr. 20:271-315.

Frenzel, B. 1968. The Pleistocene vegetation of northern Eurasia. Science 161:637-649.

Harlan, J. R. 1956. Theory and dynamics of grassland agriculture. D. Van Nostrand, Inc., Toronto. 281 p.

Harvey, L. A., and D. ST. LegerGORDON. 1953. Dartmoor. Collins, London. $170 \mathrm{p}$.

Klages, K. H. W. 1912. Ecological crop geography. The Macmillan Co., New York. 615 p.

Moore, C. W. E. 1964. Distribution of grasslands: 182-205. In Grasses and grasslands. Edited by C. Barnard. Div. of Plant Ind., Canberra, Australia. Macmillan and Co. Ltd., London.
Moss, E. H. 1952. Grassland of the Peace River region, Western Canada. Can. J. Bot. 30:98-124.

Mosquin, T. 1965. Reproductive specialization as a factor in the evolution of the Canadian flora: 43-65. In The cvolution of Canada's flora. Univ. of Toronto Press, Toronto. Oosting, H. J. 1948. The study of plant communities. W. H. Freeman and Co., San Francisco, Calif. 389 p.

Ritchie, J. C. 1965. Aspects of the late-Pleistocene history of the Canadian flora: 66-80. In The evolution of Canada's flora. Univ. of Toronto Press, Toronto.

Rowe, J. S. 1965. Phytogeographic zonation: an ecological appreciation: 12-27. In The evolution of Canada's flora. Univ. of Toronto Press, Toronto.

SANDERSon, M. 1948. The climates of Canada according to the New Thornthwaite classification. Sci. Agr. 28: 501-517.

Tansley, A. C. 1949. The British Islands and their vegetation (2 volumes). Cambridge Univ. Press. $930 \mathrm{p}$.

Trewartha, G. T. 1954. An introduction to climate. McGraw-Hill Book Co., New York, 402 p.

Thornthwaite, C. W. 1952. Grassland climates. Proc. Sixth Int. Grassland Congr: 667-675.

Thornthwaite, C. W., and F. K. Hare. 1955. Climatic classification in forestry. Unasylva 9:51-59.

Webb, R., A. Johnston, ANd J. D. SOPER. 1967. The prairie world: 93-115. In Alberta, a natural history. M. G. Hurtig, Edmonton, Alta. Wilsie, C. P. 1962. Crop adaptation and distribution. W. H. Freeman and Co., London. 448 p.

Woolfolk, E. J., D. F. Costello, and B. W. Allred. 1948. The major range types: 205-211. In Grass. Yearbook of Agr., U.S.D.A.

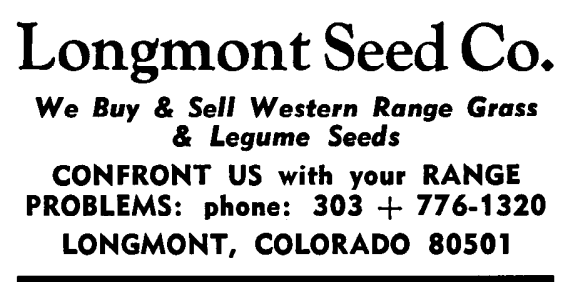

